\title{
Hydrogeochemistry of thermal waters of the Baikal Rift, South-Eastern Tuva, Russia
}

\author{
Anastasia Shestakova ${ }^{1,2, *}$, Natalia Guseva ${ }^{1}$, Yulia Kopylova $^{1}$, Albina Khvaschevskaya $^{1}$, and \\ Kara-Kys Arakchaa ${ }^{3}$ \\ ${ }^{1}$ National Research Tomsk Polytechnic University, 30 Lenina Avenue, Tomsk 634050, Russia \\ ${ }^{2}$ Tomsk Department of the Trofimuk Institute of Petroleum-Gas Geology and Geophysics of Siberian \\ Branch of the Russian Academy of Sciences, Tomsk 634055, Russia \\ ${ }^{3}$ Research Institute of Medical and Social Problems and Management of the Republic of Tuva, 48 \\ Lenina Avenue, Kyzyl 667000, Russia
}

\begin{abstract}
The spa resort of the Ush-Beldir is located in the south-eastern part of the Tuva region, Russia in the zone of influence of the Baikal rift. The Ush-Beldir territory has about 10 thermal springs and 4 exploration wells used for treatment and prevention of diseases. Hydrological and hydrochemical features of the thermal groundwaters are considered. The studied waters are thermal $\left(\mathrm{T}=50-83^{\circ} \mathrm{C}\right)$, alkaline $(\mathrm{pH}=9.3-10)$, low mineralized (TDS $<370 \mathrm{mg} / \mathrm{L}$ ) $\mathrm{Na}-\mathrm{HCO}_{3}$ waters with a high content of $\mathrm{SiO}_{2}$ (up to $125 \mathrm{mg} / \mathrm{L}$ ) and $\mathrm{F}$ (up to $14 \mathrm{mg} / \mathrm{L}$ ). The correlation of $\mathrm{F}^{-}$with $\mathrm{SiO}_{2}, \mathrm{HCO}_{3}{ }^{-}, \mathrm{Cl}^{-}, \mathrm{Na}^{+}$as well as the calculation of saturation indices of minerals, allows one plausible solute source for these thermal waters, viz. the dissolution of rock-forming aluminosilicates, most likely plagioclase, gabbro and/or amphiboles in shales.
\end{abstract}

\section{Introduction}

Thermal waters are typically distributed in zones of Alpine folding (OligoceneMiocene) and Cenozoic volcanic areas [1]. Geothermal systems and manifestations of thermal waters are well-known and common in many areas of the world such as Turkey, Mexico, China, Italy, and Russia, and their exploitation may be advantageous in terms of accessibility, distribution and cost. Thermal springs can be used directly as an energy source, in many countries, geothermal resources are used for bathing, heating, greenhouses $[2,3,4]$. A large number of the thermal waters in Russia are concentrated in Kamchatka, Primorye, Caucasus, Baikal and the Rift Zone (BRZ). Among the variety of thermal waters are allocated $\mathrm{Na}-\mathrm{HCO}_{3}$ thermal waters or nitrogen/soda thermal waters [5-7]. Distinctive features of $\mathrm{Na}-\mathrm{HCO}_{3}$ thermal waters are low total dissolved solids (overwhelmingly up to $1 \mathrm{~g} / \mathrm{L}$ ), almost exclusively the sodium composition of the cations, a high temperature, the alkaline reaction and the dominant nitrogen $\left(\mathrm{N}_{2}\right)$ in gas composition.

In Russia, one of the regions having large reserves of fresh water and different kinds of mineral groundwater is the Tuva Republic [8]. This study pays attention to characterization

\footnotetext{
*Corresponding author: ashest91@mail.ru
} 
of the chemical composition of the thermal $\mathrm{Na}-\mathrm{HCO}_{3}$ waters of the Ush-Beldir territory (Tuva Republic), and calculation of the saturation indices of these waters with respect to secondary minerals, with the central focus on the identification of chemical processes influences on chemical composition.

\section{Sampling and methods}

The spa resort of Ush-Beldir is located at an altitude of $1120 \mathrm{~m}$ above sea level in the southeast part of the Tuva Republic close to the border with Mongolia, and is a large deposit of $\mathrm{Na}-\mathrm{HCO}_{3}$ thermal waters. Water sources are located in the Prikhubsugulsky highland at an absolute height of $1120 \mathrm{~m}$ at the confluence of three rivers: the ShishkhidGol, Belin and Busin-Gol. The Ush-Beldir territory has about 10 thermal springs and 4 exploration wells. Thermal waters are used for physiotherapeutic procedures, domestic needs and heating of the sanatorium buildings. These thermal springs have a special cultural value among the local population, and the study area is included in a national park.

The eastern part of the Tuva region is the western margin of the Baikal Rift Zone, where numerous thermal springs are associated with zones of late Cenozoic volcanism and the fault arrays. The formation of thermal springs is associated with the zones of Late Cenozoic volcanism in the territory of Eastern Tuva. The Ush-Beldir springs discharge along N-S tend large faults. Rocks are represented by metamorphic strata of the Upper Proterozoic (gneiss, quartzite, shale) and the Sinia Complex (marbles, metamorphic crystalline schists), as well as Lower Paleozoic (gabbros, diorites, gabbro-diorites) and Devonian intrusions (granites, syenites). Cold waters are found in alluvial Quaternary deposits and in the fractured massif, surrounding the thermal waters. On the bottom of the geological section of the wells are located coarse-grained syenites, consisting of plagioclase, microcline, biotite, hornblende, pyrite, chalcopyrite and chlorite. Dark-gray gabbros lie above syenite and are represented by plagioclase, hornblende and amphibole. Pliocene-Quaternary alluvium is composed of gravelstone, sandstone, limestone, tuff, sand, clay and silt deposits that have accumulated within the Shishkhid-Gol river.

The authors took samples from springs and wells in the Ush-Beldir territory in the summer of 2015 for chemical characterization (Fig. 1). Nine thermal waters and one cold groundwater were sampled in polyethylene bottles for hydrochemical analysis.

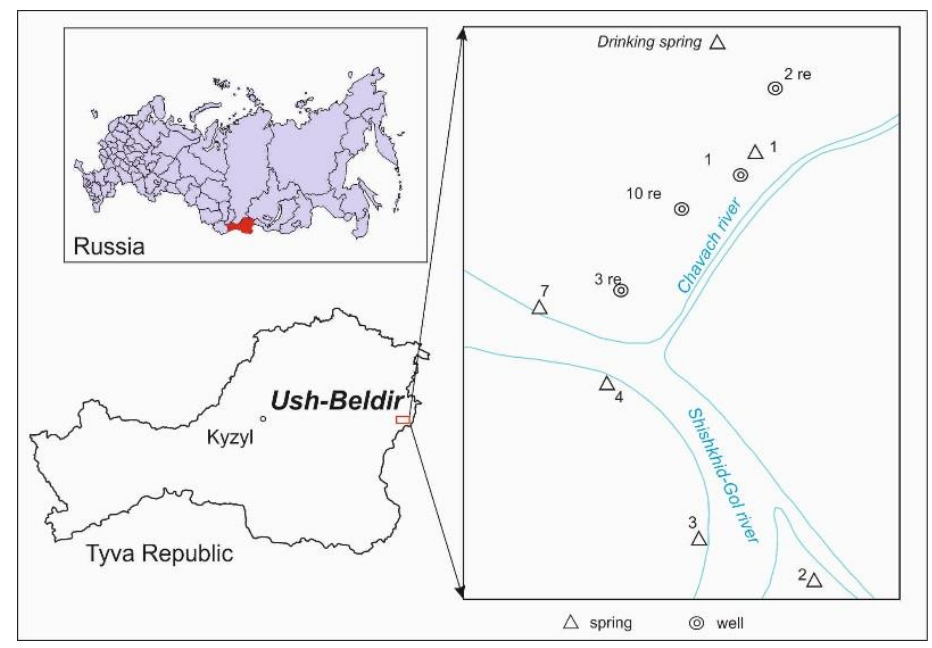

Fig. 1. Location of the sampling points of the Ush-Beldir territory. 
The $\mathrm{pH}$, electrical conductivity $(\mathrm{EC})$, redox potential $(\mathrm{Eh})$ and temperature $\left(\mathrm{T}^{\circ} \mathrm{C}\right)$ of the water were measured at the discharge temperature in situ using a portable device Water Test (Hanna Instruments, Germany), and the dissolved solids were determined in the laboratory. The samples for trace elements analyses were stored in $50 \mathrm{ml}$ clean polyethylene bottles and were immediately acidified with concentrated $\mathrm{HNO}_{3}$ to prevent metal precipitation. The concentration of $\mathrm{HCO}_{3}$ was determined by titration method with $0.01 \mathrm{~N}$ solution of $\mathrm{HCl}$ against methyl orange indicator. Cations and anions were determined using ion chromatography (Dionex 1000 and Dionex 2000). The quality of the analyses was evaluated using charge balance (IB) technic and samples with IB $>5 \%$ were excluded from further study. Dissolved trace elements were determined by inductively coupled mass spectrometry (ICP-MS, Perkin Elmer, ELAN-DRC-e). All standard solutions were prepared with ultra-pure deionized water and Perkin Elmer Multi Element Standard Solutions. Saturation index (SI) was calculated using PHREEQC software complex with the Lawrence Livermore National Laboratory database (1lnl) at reservoir temperature for calculation of thermodynamic equilibrium condition of waters with respect to the main mineral phases. Thus, SI $>0$ reflects oversaturation conditions; SI $<0$ denotes undersaturation conditions.

\section{Results and discussion}

Analytical results of major components in the groundwater samples are given in Table 1. The groundwaters of Ush-Beldir belong to $\mathrm{Na}-\mathrm{HCO}_{3}$ type with high $\mathrm{pH}$ values from 9.3 to 10 , and a strongly reducing medium (Eh from -60 to $-482 \mathrm{mV}$ ). Samples collected from the exploration wells are characterized by high temperatures varying from 72 to $83^{\circ} \mathrm{C}$, waters with a lower temperature $\left(50-75^{\circ} \mathrm{C}\right)$ are the natural spring waters, while the chemical composition of thermal waters in wells and springs are almost identical.

Table 1. Chemical composition of groundwaters in the Ush-Beldir territory, mg/L.

\begin{tabular}{|c|c|c|c|c|c|c|c|c|c|}
\hline & \multicolumn{9}{|c|}{ Samples } \\
\hline & \multicolumn{4}{|c|}{ Well number } & \multicolumn{5}{|c|}{ Spring number/name } \\
\hline & 2re & 1 & 3re & 10re & 1 & 7 & 3 & 2 & $\begin{array}{c}\text { «Drinking } \\
\text { spring» }\end{array}$ \\
\hline $\mathrm{T},{ }^{\circ} \mathrm{C}$ & 72 & 81 & 83 & 83 & 75 & 50 & 56 & 59 & 1.5 \\
\hline $\mathrm{t}^{* *},{ }^{\circ} \mathrm{C}$ & 145 & 141 & 142 & 146 & 143 & 130 & 140 & 140 & - \\
\hline $\mathrm{pH}$ & 9.7 & 9.4 & 9.5 & 9.3 & 9.6 & 9.7 & 9.8 & 10.0 & 7.8 \\
\hline Eh, mV & -466 & -400 & -476 & -482 & -460 & -60 & -464 & -400 & 157 \\
\hline $\mathrm{CO}_{3}^{-}$ & 84 & 90 & 87 & 84 & 90 & 66 & 69 & 75 & 0 \\
\hline $\mathrm{HCO}_{3}^{-}$ & 104 & 104 & 110 & 113 & 101 & 91.5 & 95.2 & 113 & 122 \\
\hline $\mathrm{SO}_{4}^{2-}$ & 32 & 27 & 26 & 27 & 30 & 53 & 48 & 36 & 20 \\
\hline $\mathrm{Cl}^{-}$ & 23 & 22 & 21 & 20 & 23 & 19 & 21 & 19 & 0.39 \\
\hline $\mathrm{Ca}^{2+}$ & 1.0 & 1.3 & 2.1 & 2.5 & 1.0 & 3.4 & 2.8 & 2.3 & 41 \\
\hline $\mathrm{Mg}^{2+}$ & 0.6 & 0.6 & 0.6 & 0.4 & 0.6 & 0.5 & 0.5 & 0.5 & 3.4 \\
\hline $\mathrm{Na}^{+}$ & 111 & 111 & 111 & 111 & 114 & 104 & 106 & 108 & 1.7 \\
\hline $\mathrm{K}^{+}$ & 3.5 & 3.4 & 3.4 & 3.4 & 3.6 & 2.8 & 3.1 & 2.9 & 2.1 \\
\hline TDS* & 373 & 372 & 374 & 374 & 377 & 352 & 358 & 369 & 191 \\
\hline $\mathrm{SiO}_{2}$ & 125 & 115 & 116 & 122 & 121 & 93 & 113 & 111 & 10 \\
\hline $\mathrm{F}^{-}$ & 14 & 13 & 13 & 13 & 14 & 12 & 13 & 12 & 0.29 \\
\hline $\mathrm{Fe}$ & 0.001 & 0.004 & 0.004 & 0.005 & 0.50 & 0.03 & 0.13 & 0.01 & 0.04 \\
\hline $\begin{array}{l}\text { Water } \\
\text { type }\end{array}$ & & & & $\mathrm{HCO}_{3}$ & $\left.\mathrm{O}_{3}\right)$ & & & & $\mathrm{Ca}-\mathrm{SO}_{4}-\mathrm{HCO}_{3}$ \\
\hline
\end{tabular}

* Total Dissolved Solids. $\mathrm{t}$ - reservoir temperature calculated with using $\mathrm{SiO}_{2}$ geothermometer (Fournier and Potter, 1982) [8]. 
Based on major ion chemistry, thermal waters in wells and springs are generally classified as $\mathrm{Na}-\left(\mathrm{HCO}_{3}+\mathrm{CO}_{3}^{-}\right)$with a low content of $\mathrm{Ca}$ and $\mathrm{Mg}$ in groundwater and, accordingly, low values of TDS ranging from 352 to $370 \mathrm{mg} / \mathrm{L}$. The dissolved and spontaneous gases of the considered thermal waters are mainly represented by nitrogen (95 vol.\%) with $\mathrm{CH}_{4}$ impurity 1.96 vol.\%, $\mathrm{O}_{2}-1.2$ vol.\%, $\mathrm{Ar}-0.7$ vol.\%, and $\mathrm{He}-$ 0.5 vol.\% according with [9]. Dominance in the gas composition of nitrogen, oxygen and argon probably suggests their atmospheric origin. A low proportion of oxygen in gas composition may indicates oxidation of organic matter, iron or sulphides. The studied thermal waters are riched in $\mathrm{SiO}_{2}$ and $\mathrm{F}$ with concentrations up to 125 and $14 \mathrm{mg} / \mathrm{L}$ respectively. Moreover, their concentrations grow with increasing of $\mathrm{pH}$ and temperature. The high concentrations of $\mathrm{SiO}_{2}$ reflects a high geothermal reservoir temperatures. This is confirmed by the calculations of deep temperatures with using a $\mathrm{SiO}_{2}$ geothermometer (Fournier and Potter, 1982). The temperature of the reservoir is estimated about $130-146^{\circ} \mathrm{C}$ (Table 1).

Correlation coefficient is a commonly used measure to establish the relation between independent and dependent variables. A direct dependence between the content of fluoride and carbonate ions was established in the thermal and cold groundwaters, but fluoride poorly correlates with sulfate. From correlation study it was observed that the contents of $\mathrm{SiO}_{2}, \mathrm{HCO}_{3}{ }^{-}, \mathrm{Cl}^{-}$and $\mathrm{Na}^{+}$are positively correlated with $\mathrm{F}^{-}$. This probably indicates a single rock source for these components in groundwater, most likely shale (composed of plagioclase-biotite-amphibole) or gabbros and, which contain these elements. In addition, alkali metal fluorides ( $\mathrm{K}$ and $\mathrm{Na}$ ), unlike $\mathrm{Ca}$ and $\mathrm{Mg}$ fluorides, are very soluble in groundwater and capable of active migration.

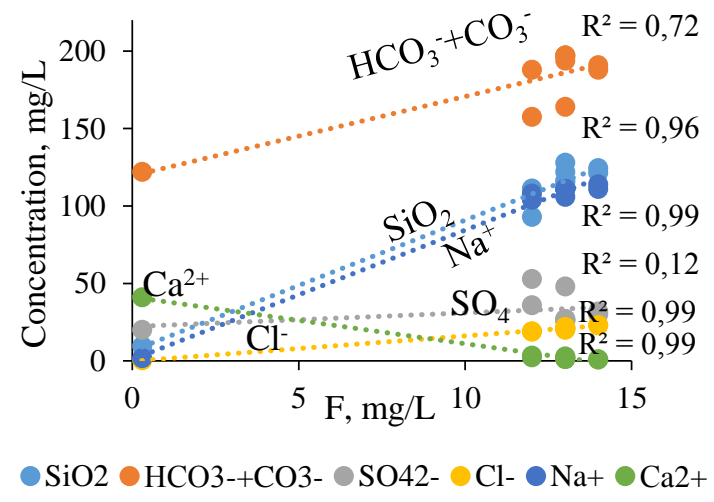

Fig. 2. $\mathrm{HCO}_{3}+\mathrm{CO}_{3}, \mathrm{SiO}_{2}, \mathrm{SO}_{4}, \mathrm{Na}, \mathrm{Ca}, \mathrm{Cl}$ (in $\mathrm{mg} / \mathrm{L}$ ) vs. $\mathrm{F}$ (in $\mathrm{mg} / \mathrm{L}$ ) binary diagram for the UshBeldir thermal and cold groundwaters.

Compared to the studied thermal waters, the «Drinking spring», is located in the north part of the Ush-Beldir territory. This spring has low temperature $\left(1.5^{\circ} \mathrm{C}\right)$ and belongs to $\mathrm{Ca}-\mathrm{SO}_{4}-\mathrm{HCO}_{3}$ water's type. Besides the high concentration of $\mathrm{SO}_{4}{ }^{2-}$ is associated with the presence of sulphide minerals notably pyrite and chalcopyrite. The results of the investigation indicated that these waters are distinguished by a near neutral value of $\mathrm{pH}$ (7.8), an oxidizing geochemical environment (Eh $157 \mathrm{mV}$ ) and a low TDS value (191 mg/L).

A feature of $\mathrm{Na}-\mathrm{HCO}_{3}$ waters is the predominance of sodium in the cationic composition. Low concentrations of calcium, magnesium and iron are explained by the precipitation of these elements from solution in the form of carbonates (calcite, dolomite, 
magnesite, etc.), ferrous minerals (goethite, hematite, magnetite), fluorite and possibly silicates (Fig. 3, Table 2) [5].

The temperature of groundwater ascending from depth and dissolution of host rocks are reflected in the chemical composition of spring waters in the Ush-Beldir territory. Thermal water compositions are more likely to reflect equilibrium between the waters and minerals (i.e., saturation) at deep reservoir temperatures corresponding to the temperature about $130-146^{\circ} \mathrm{C}$ (Table 1). Thermodynamic calculations, conducted at reservoir temperature, confirm that thermal waters are in equilibrium with respect to calcite, magnesite, dolomite, and magnetite (Table 2).

Table 2. Saturation indices of selected minerals calculated at the reservoir temperature.

\begin{tabular}{|l|c|c|l|c|c|}
\hline \multicolumn{1}{|c|}{ Minerals } & 2re well & $\begin{array}{c}\text { Spring } \\
\text { No7 }\end{array}$ & Minerals & 2re well & Spring №7 \\
\hline Kaolinite & -6.64 & -6.39 & Magnetite & 1.76 & 2.53 \\
\hline K-feldspar & -2.70 & -2.75 & Fluorite & -0.94 & -0.49 \\
\hline Muscovite & -6.86 & -6.67 & Quartz & -0.26 & -0.67 \\
\hline Albite & -2.64 & -2.74 & Clinochlore & 18.73 & 17.79 \\
\hline Calcite & 1.17 & 1.61 & Hematite & 2.03 & 5.78 \\
\hline Dolomite & 3.25 & 3.54 & Epidote & 1.80 & 4.31 \\
\hline Magnesite & 0.94 & 0.78 & Goethite & 0.31 & 2.22 \\
\hline
\end{tabular}

Additionally, the mineral saturation indices indicate equilibrium between the thermal waters and minerals clinochlore, epidote, hematite and goethite. The samples of the thermal waters are undersaturated with respect to albite, kaolinite, K-feldspar, muscovite, quartz, and fluorite.

\section{Conclusions}

Hydrogeochemical studies of the thermal waters of the Ush-Beldir territory have shown their specific characteristics such as high temperatures of $50-83^{\circ} \mathrm{C}$ and $\mathrm{pHs}$ of 9.3 to 10 , $\mathrm{Na}-\mathrm{HCO}_{3}$ water type with TDS about $370 \mathrm{mg} / \mathrm{L}$, and high concentrations of $\mathrm{Na}, \mathrm{SiO}_{2}, \mathrm{~F}$ compared with $\mathrm{Ca}, \mathrm{Mg}$ and $\mathrm{Fe}$. Such a relationship of elements is associated with significant precipitation of $\mathrm{Ca}, \mathrm{Mg}$ and $\mathrm{Fe}$ in the form of carbonates and aluminosilicate minerals. In addition, the high concentration of $\mathrm{SiO}_{2}$ and calculations of reservoir temperatures indicate geothermal reservoir temperatures about $145{ }^{\circ} \mathrm{C}$. The correlation $\mathrm{F}^{-}$ with $\mathrm{SiO}_{2}, \mathrm{HCO}_{3}{ }^{-}, \mathrm{Cl}^{-}$and $\mathrm{Na}^{+}$as well as the calculation of saturation indices of minerals, allows us to suggest one plausible solute source for components of thermal waters, which is the dissolution of rock-forming aluminosilicates, most likely plagioclase, gabbro and/or amphibole in shales.

Acknowledgements. The work was supported by Russian Science Foundation Project № 17-1701158 .

\section{References}

1. Petar Papic, Mineral and Thermal Waters of Southeastern Europe (Springer, 2015)

2. F.B. Brahim, J. Makni, S. Bouri, H. B. Dhia, Arab. J. Sci. Eng., 39 (2014)

3. Yu. Demonova, N. A. Kharitonova, A. V. Korzun A. I. Sardorov, G. A. Chelnokov, Bul. Mos. Univ. Geol., 72, 6 (2017)

4. J. Li, D.J. DePaolo, Y.X. Wang, X. Xie, J. Hydr., 559 (2018) 
5. L.V. Zamana, Geoch. Int. J., 38, 11 (2000)

6. I.V. Bragin, G.A. Chelnokov, O.V. Chudaev, N.A. Kharitonova, S.V. Vysotskiy, Acta Geol. Sin., 90, 1 (2016)

7. N.A. Kharitonova, G.A.Chelnokov, A.A.Karabtsov, V.I.Kiselev, Appl. Geoch. J., 22, 8 (2007)

8. A.V. Shestakova, N.V. Guseva, Bull. Tomsk Polytech. Univ. Geo. Assets. Eng., 329, 1 (2018)

9. Ministry of Health of the USSR, Report on a comprehensive survey of hydromineral and mud resources of the Tuva ASSR (Geominvod, 1966). 